\title{
Foraging behavior and diet of the vulnerable Cinereous Warbling-finch Poospiza cinerea (Aves, Emberizidae)
}

\author{
Wischhoff, U., ${ }^{a, b}$, Marques-Santos, $F^{a, b}$ and Rodrigues, $M .^{a}$ \\ aLaboratório de Ornitologia, Departamento de Zoologia, Universidade Federal de Minas Gerais - UFMG, \\ Avenida Antônio Carlos, 6627, CP 486, Pampulha, CEP 31270-901, Belo Horizonte, MG, Brazil \\ bPrograma de Pós-graduação em Ecologia e Conservação, Setor de Ciências Biológicas, Universidade \\ Federal do Paraná - UFPR, Av. Cel. Francisco Heráclito dos Santos, 100, Jardim das Américas, \\ CEP 81531-990, CP 19031, Curitiba, PR, Brazil \\ *e-mail: uschiw@gmail.com
}

Received: April 4, 2013 - Accepted: June 18, 2013

(With 4 figures)

\begin{abstract}
The Cinereous Warbling-finch Poospiza cinerea is a globally vulnerable Emberizidae passerine, patchily distributed and rare in the open savannah of central South America. Attributes of rare species include niche specificity such as feeding habits. To verify possible niche specialization in this species we aimed to describe its foraging habits related to substrate use, foraging and substrate height, attack maneuvers, and consumed food items. We monitored two groups at two study sites and sampled foraging events with intervals of 15 minutes. The substrates used in greater frequency were foliage and reproductive organs. Foraging and substrate height varied widely with study area. The attack maneuver adopted in greater frequency was glean. Most food items attacked were small invertebrates. Big invertebrates included Lepidoptera, Hemiptera, Coleoptera, Hymenoptera and Orthoptera. Poospiza cinerea was also recorded foraging in mixed bird flocks with seven other species. The generalist foraging behavior of the species cannot be associate to its rarity.
\end{abstract}

Keywords: attack maneuver, feeding behavior, niche specificity, rarity, substrate choice.

\section{Comportamento de forrageamento e dieta do vulnerável capacetinho-do-oco- do-pau Poospiza cinerea (Aves, Emberizidae)}

\section{Resumo}

O capacetinho-do-oco-do-pau Poospiza cinerea é um passeriforme da família Emberizidae globalmente vulnerável, irregularmente distribuído e raro no Cerrado do centro da América do Sul. Atributos de espécies raras incluem especificidades de nicho tais como hábitos de forrageamento. Para verificar possível especialização de nicho dessa espécie, buscamos descrever seu comportamento de forrageamento relacionado a uso de substrato, altura de forrageamento e do substrato, manobras de ataque e itens alimentares consumidos. Nós monitoramos dois grupos em duas áreas de estudo e amostramos eventos de forrageamento com intervalos de 15 minutos. Os substratos utilizados em maior frequência foram folhagem e órgãos reprodutivos. Alturas de forrageamento e dos substratos variaram amplamente com a área de estudo. A manobra de ataque adotada em maior frequência foi respigar. A maioria dos itens alimentares foi pequenos invertebrados. Grandes invertebrados incluíram Lepidoptera, Hemiptera, Coleoptera, Hymenoptera e Orthoptera. Poospiza cinerea foi registrado forrageando em bandos mistos com outras sete espécies. O comportamento de forrageamento generalista da espécie não pode ser associado com sua raridade.

Palavras-chave: manobra de ataque, comportamento alimentar, especificidade de nicho, raridade, escolha de substrato.

\section{Introduction}

The Cinereous Warbling-Finch Poospiza cinerea Bonaparte 1850 is a Neotropical grassland passerine bird that belongs to the family Emberizidae and is currently threatened, assigned as vulnerable globally (BirdLife International, 2011). Yet, descriptive studies on this species autecology were absent until Wischhoff et al. (2012) and Costa and Rodrigues (2013). Poospiza cinerea occurs patchily in mountaintops ranging from 600 to $1,400 \mathrm{~m}$ (Ridgely and Tudor, 1989; Stotz et al., 1996; Lopes et al., 2010; Vasconcelos and Rodrigues, 2010) and is considered rare and endemic to the Cerrado (Silva, 1997), a savannahlike biome regarded as a biodiversity hotspot (Oliveira and Marquis, 2002). Since tropical grasslands are being lost at an alarming rate due to losses from agriculture and urban 
development (Vickery et al., 1999), it is urgent to assess basic life-history data on species depending on this habitat.

Habitat and niche specificity, geographical range and local population density are species attributes that can explain rarity (Brown, 1971; Rabinowitz, 1981). In birds, many ecological and life-history traits have been shown to be correlated with rarity, such as body size, dispersal ability, reproductive traits, habitat specificity, diet and migratory status (review in Sodhi et al., 2004). To verify possible niche specialization in this species we aimed to describe its foraging habits related to substrate use, foraging and substrate height, attack maneuvers behavior, and consumed food items. Based on its alluded rarity, we expect that $P$. cinerea presents some level of specialization.

\section{Material and methods}

\subsection{Study areas}

Field work took place in two different areas in the state of Minas Gerais, southeastern Brazil:

(1) Paredão da Serra do Curral Municipal Park (1957' $\left.\mathrm{S} 43^{\circ} 55^{\prime} \mathrm{W}\right)$ : located on the borders of the city of Belo Horizonte, which has over 2 million citizens. The annual mean rainfall is $1,560 \mathrm{~mm}$ and average temperature in 2010 was $23.2^{\circ} \mathrm{C}$ (INMET, 2011). The vegetation consists mainly of campo cerrado (grassland with scattered shrubs and trees) and campo rupestre sobre canga (rocky outcrops with predominance of grass on ferruginous soil) (Vasconcelos, 2007), typical of the Cerrado biome. The area is heavily degraded by mining, illegal burns and settlement of exotic species. Field work was carried out in this area from July to November 2010 and in April 2011.

(2) Morro da Pedreira Area of Environmental Protection $\left(19^{\circ} 17^{\prime} \mathrm{S} 43^{\circ} 35^{\prime} \mathrm{W}\right)$ : average annual precipitation is $1,622 \mathrm{~mm}$ and average annual temperature is $21.2^{\circ} \mathrm{C}$ (Medina and Fernandes, 2007). The vegetation consisted mainly of campo limpo (grassland), campo rupestre (rocky outcrops with predominance of grass) and cerrado rupestre (rocky outcrops with predominance of shrubs and trees) (based on Ribeiro and Walter, 1998). The area surrounds Serra do Cipó National Park and is therefore less degraded. Field work was carried out from December 2010 to May 2011, except January 2011.

One group of $P$. cinerea was monitored in each area. Despite our capture efforts (a total of 89 net-hours), we were able to color-band only one or two individuals from each group, and therefore did not account for individual variation in behavior. In Area 1 the group was initially composed of four individuals, but one disappeared during the study period. In Area 2 the group was composed of three individuals, but a young joined the group at some point between December and February. The young in Area 2 could be discerned from the other individuals by its brownish and cream colors, in contrast to the grey and white of the adults. Unlike what has been previously reported, the ear coverts and lores were of a lighter tone than in the adults, while the eyes were darker (Costa and Rodrigues 2013).

\subsection{Foraging behavior}

We used the nomenclature for attack maneuvers and food-handling techniques described in Remsen and Robinson (1990). The substrates were classified as foliage, rock or ground, air, trunk or branch and reproductive organs, which included flower and fruit clusters. The food items were small invertebrates, when smaller than $1 \mathrm{~cm}$, big invertebrates and flower/fruit/seed, the last were grouped because of the uncertainty of what was effectively ingested. For each foraging event the attack maneuver, substrate, food item, foraging height and total substrate height were recorded, having these last two categories been estimated visually to intervals of $0.5 \mathrm{~m}$ when the substrates were plants. When it was not possible to obtain the data for one or more of these categories, the event was recorded with the available information only. We also identified the plants used as substrate and as food to the lower taxonomic level possible. We took note of the species which Poospiza cinerea joined in mixed flocks, but sampling took no other account of them.

The observations were made with the aid of $8 \times 40$ binoculars. Sampling schedule ranged from 5:00 to 18:00 and the number of events in each time of day varied with the group's intensity of activity and our knowledge of its location. After the group was located, the first foraging event was recorded (following Recher and Gebski, 1990). The subsequent event was recorded only after 15 minutes if the same individual was seen foraging or immediately if it was another individual. Since the groups were small and roughly half of the individuals was identifiable (based on age or color-bands), normally we could keep track of each individual's location. If in doubt of identity, we waited another 15 minutes to resample a specific individual. We chose this sampling interval based on preliminary observations, which showed that 15 minutes provided biologically independent observations, because within this interval individuals had enough time to change foraging patches (Lair, 1987).

\subsection{Statistical analysis}

We used Fisher's exact test to compare areas according to attack maneuvers employed and substrates explored, since more than $20 \%$ of the cells had expected values under 5. Pearson chi-squared test was used to compare food items consumption between areas. Spearman correlation was used between foraging height and substrate height, because our data did not have a normal distribution. All tests were conducted with JMP (SAS Institute, 2012) and a level of significance of 0.05 was adopted. Means are reported together with standard deviations. 


\section{Results}

After 180 sampling hours in Area 1 and 110, in Area 2, we obtained a total of 149 foraging events (Table 1), which was considered an adequate sampling (Recher and Gebski, 1990).

Overall, near-perch maneuvers prevailed (97\% in area 1 and 99\% in Area 2) over aerial maneuvers. The near-perch maneuver used with higher frequency in both areas was glean (Figure 1). Attack maneuvers' choice was not different between areas (Fisher's exact test, $\mathrm{p}=0.37$ ).

The substrates most used in both areas were foliage and reproductive organs (Figure 2) and frequency of use was not different between areas (Fisher's exact test, $\mathrm{p}=0.31)$. In Area 1 the substrate height ranged from 0 to $12 \mathrm{~m}(\overline{\mathrm{x}}=4.0 \pm 3.4$; Figure 3$)$, and in Area 2, from 0 to $6 \mathrm{~m}(\overline{\mathrm{x}}=1.6 \pm 0.9)$. Foraging height ranged from 0 to $10 \mathrm{~m}$ in Area $1(\overline{\mathrm{x}}=2.9 \pm 2.3)$ and 0 to $6 \mathrm{~m}$ in Area 2 $(\overline{\mathrm{x}}=1.4 \pm 0.9)$. We verified that in both areas the foraging height was correlated to the substrate height (Area 1: Spearman, $\mathrm{r}_{\mathrm{s}}=0.94 ; \mathrm{p}<0.05 ; \mathrm{n}=62$. Area 2: Spearman, $\mathrm{r}_{\mathrm{s}}$ $=0.93 ; \mathrm{p}<0.05 ; \mathrm{n}=80)$, indicating that total plant height determines foraging height.

Table 1. Number of foraging events by Poospiza cinerea recorded in each study area. Most variables were collected simultaneously per event.

\begin{tabular}{lccc}
\hline & Area 1 & Area 2 & Total \\
\hline Total number of events & 63 & 86 & 149 \\
Attack maneuver & 63 & 80 & 143 \\
Substrate & 60 & 76 & 136 \\
Food item & 51 & 72 & 123 \\
Foraging height & 60 & 81 & 141 \\
Substrate height & 60 & 80 & 140 \\
\hline
\end{tabular}

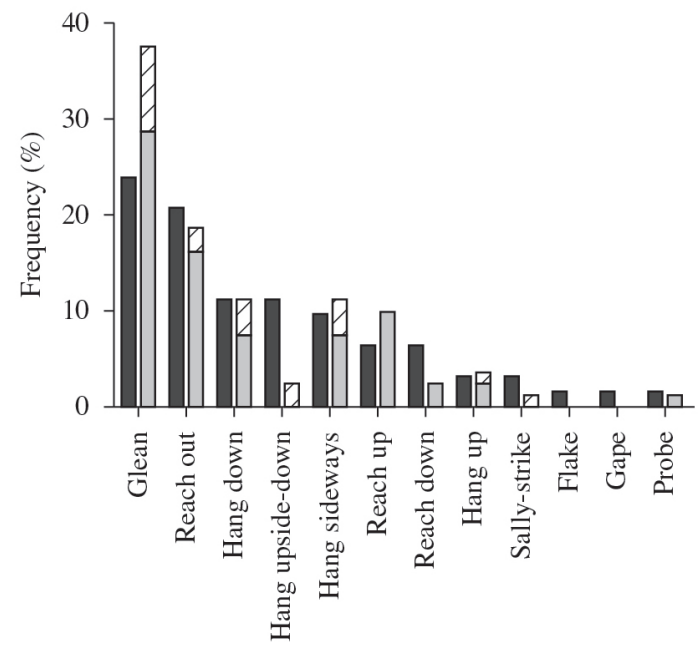

Area $1 \square$ Area 2: adults $\square$ Area 2: young

Figure 1. Frequency of attack maneuvers by Poospiza cinerea in both study areas. In area 2 , we indicate the frequency of use of each attack maneuver by the adults and the young. For sample sizes, refer to Table 1.
Plant families that were used as substrate were Asteraceae, Bromeliaceae, Casuarinaceae, Dilleniaceae, Ericaceae, Fabaceae, Loranthaceae, Lythraceae, Malpighiaceae, Malvaceae, Melastomataceae, Myrtaceae, Poaceae, Polygonaceae, Rubiaceae, Sapindaceae, Styracaceae, Urticaceae, Verbenaceae, Vochysiaceae, being some families exclusive of one of the areas. During unsystematic observations in Area 1, P. cinerea used Pinus sp. (Pinaceae) $(\mathrm{n}=2)$ and a non-identified fern $(\mathrm{n}=1)$ as substrates. Poaceae had spikelets consumed in Area 2 only during unsystematic observations $(\mathrm{n}=1)$.

The food item most consumed was small invertebrates in both areas (Figure 4). The frequency of consumption of food items was different between areas (Pearson chi-squared test, $\mathrm{p}<0.05$ ). The plant family which had most frequently vegetal matter consumed was Asteraceae (Table 2). We were able to collect one dropping which contained small seeds, $\leq 1 \mathrm{~mm}$, which resembled Melastomataceae seeds. Invertebrates identified in field included Lepidoptera, Hemiptera (Heteroptera), Coleoptera, Hymenoptera (Formicidae), and Orthoptera, having all been classified as big invertebrates. Food-handling techniques observed included mash, used specially for berries, spikelets (Poaceae) and cypselae (Asteraceae); bite, for drupes; gulp, for small invertebrates; and tear, for big invertebrates.

During observations we were able to see that individuals move constantly and quickly (more than 10 times per minute) among the vegetation and perform frequent hops and short-distance flights between patches.

Poospiza cinerea was seen, only in Area 2, in mixed flocks with the species: Polystictus superciliaris (Wied, 1831), Pseudoleistes guirahuro (Vieillot, 1819), Mimus saturninus (Lichtenstein, 1823), Saltatricula atricollis

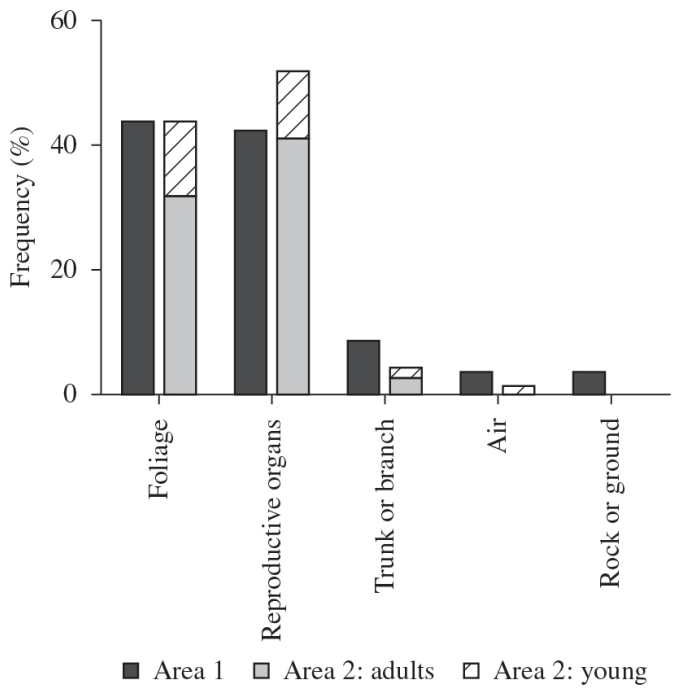

Figure 2. Frequency of substrate use by Poospiza cinerea in both study areas. In area 2, we indicate the frequency of use of each substrate by the adults and the young. For sample sizes, refer to Table 1 . 


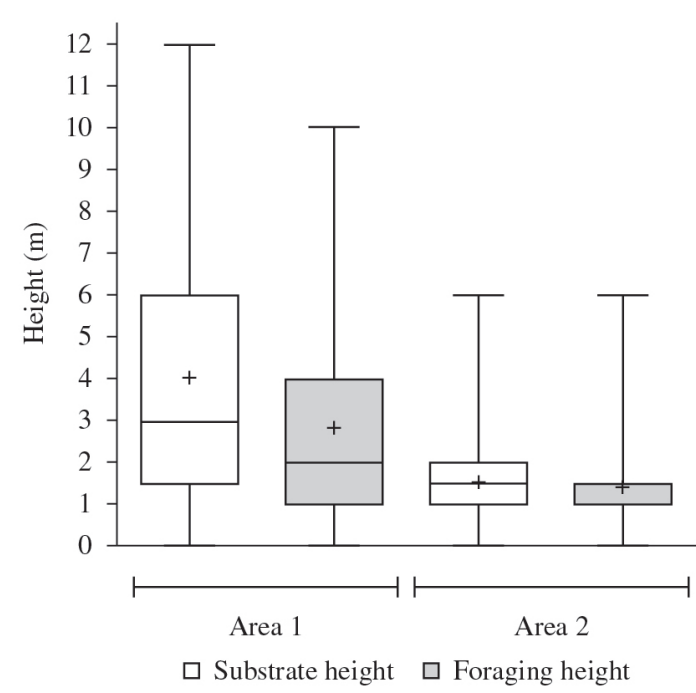

Figure 3. Boxplot of substrate height and foraging height recorded in Area 1 and Area 2. Whiskers indicate minimum and maximum height. Crosses indicate mean values. For sample sizes, refer to Table 1.

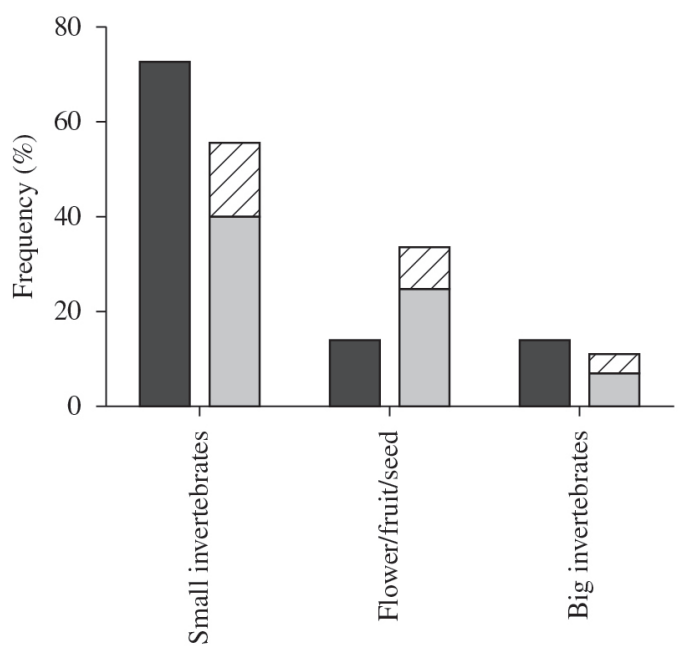

- Area $1 \square$ Area 2: adults $\square$ Area 2: young

Figure 4. Frequency of food items consumption in both study areas by Poospiza cinerea. In area 2, we indicate the frequency of consumption of each food item by the adults and the young. For sample sizes, refer to Table 1 .

(Vieillot, 1817), Schistochlamys ruficapillus (Vieillot, 1817), Tangara cayana (Linnaeus, 1766) and Zonotrichia capensis (Statius Muller, 1776).

The young made begging display throughout February and March to the other group members. During one systematic observation he was fed by the color-banded female believed to be the parent (captured with egg in abdomen on 8 Dec. 2010). The young also searched for food autonomously (Figures 1, 2 and 3).

\section{Discussion}

Poospiza cinera showed no variation in attack maneuvers or substrate choice between study areas, but food items were different. This shows plasticity in its foraging behavior and this variation can be attributed to some external factors, such as food distribution and abundance; habitat type; weather; season of the year; age of young; and interspecific social environment (Grubb, 1979). Considering that the areas are apart and have different anthropogenic disturbance levels, it is reasonable to say that abundance and distribution of food are different. However, we did not measure food availability and are not able to confirm this speculation. Also, the habitat of the two areas is very dissimilar (Marques-Santos unpubl. data). In Area 1, for example, we have a high availability of exotic species, like Casuarina sp., Pinus sp., and Eucalyptus sp., that do not have the typical height of plants of Area 2. Areas were sampled predominantly in different seasons (Area 1 in winter and spring; Area 2 in summer and autumn), which possibly is the explanation for differences in food items consumption. Adults can also alter their feeding targets according to their nutritious needs. Accordingly, in Area 2 there was a young that was fed by the adults and in Area 1 a clutch was laid during our sampling effort (Wischhoff et al., 2012). Finally, the composition of bird species of the two areas is different (see Vasconcelos, 2007; Costa and Rodrigues, 2012) and only in Area 2 was $P$. cinerea seen in mixed flocks. The social environment can alter a bird's behavior because: niche breadth is altered by species' dominance; prey can become available in response to other species presence; or foraging behavior is imitative (Grubb, 1979).

The maneuvers used by $P$. cinerea are similar to those of P. thoracica (Nordmann, 1835) (Parrini et al., 2009). Both species use glean, reach, hang and gape, but $P$. thoracica further uses sally-pounce. Using the 50\% criteria of Fitzpatrick (1980), P. cinerea could only be considered a near-perch maneuvers specialist.

The choice of substrate by $P$. cinerea is not typical of Emberizinae species, which get seeds from the ground or culm (Sick, 1997). Poospiza cinerea used foliage and reproductive organs, which matches the substrate foliage that Ridgely and Tudor (1989) have reported for P. torquata (D’Orbigny \& Lafresnaye, 1837), P. melanoleuca (d'Orbigny \& Lafresnaye, 1837), P. erythrophrys Sclater, 1881 and P. alticola Salvin, 1895. Poospiza thoracica forages additionally on branches and $P$. nigrorufa (d'Orbigny $\&$ Lafresnaye, 1837) forages on the ground. In Area 2, P. cinerea foraged more than $50 \%$ of events on reproductive organs. However, since this frequency was not matched in Area 1, we cannot consider the species a specialist this substrate (Fitzpatrick, 1980).

The positive correlations between foraging height and substrate height indicate that the species does not have a foraging pattern related to the distance to the ground but to the top of the substrate, which is in accordance with the placement of the substrates used in greater proportion: 
Table 2. Vegetable matter consumed by Poospiza cinerea.

\begin{tabular}{llcc}
\hline \multicolumn{1}{c}{ Family } & \multicolumn{1}{c}{ Species } & Vegetable matter consumed & Number of events \\
\hline ASTERACEAE & Baccharis sp. & flower/cypsela & 1 \\
& Morphotype 1 & flower/cypsela & 8 \\
& Morphotype 2 & flower/cypsela & 1 \\
DILLENIACEAE & Davilla sp. & atrophic ovary (?) & 1 \\
ERICACEAE & Gaylussacea sp. & fruit & 2 \\
LYTHRACEAE & Cuphea sp. & flower & 5 \\
MELASTOMATACEAE & Clidemia urceolata & berry & 1 \\
& Leandra cf. aurea & capsule fruit & 3 \\
& Marcetia taxifolia & berry & 1 \\
POACEAE & Miconia ligustroides & spikelet & 1 \\
STYRACACEAE & Brachiaria sp. & drupe & 2 \\
\hline
\end{tabular}

(?) Uncertain.

foliage and reproductive organs. In Area 1, P. cinerea explored a wider range of substrate heights, which is related to the substrate availability in that habitat. As an Emberizinae, one could expect that the species would forage in lower heights than observed, i.e. in the ground and Poaceae plants. The relationship between substrate and foraging heights illustrates the species plasticity, foraging in higher substrate when available.

Among the taxa chosen by $P$. cinerea for foraging are: Casuarina equisetifolia (Casuarinaceae), which is exotic and invasive in Brazil (Santana and Encinas, 2008); two exotic genera in Brazil, Brachiaria sp. (Poaceae) (Espíndola et al., 2005) and Pinus sp. (Pinaceae) (Espíndola et al., 2005); and Cecropia sp. (Urticaceae), a plant typical of secondary formations (Souza and Lorenzi, 2008). These choices show that, concerning its foraging requirements, $P$. cinerea is able to survive in a modified habitat, and might not be strongly susceptible to habitat changes.

Unlike a great number of Emberizinae, $P$. cinerea's diet is not based on seeds, but on invertebrates. Sigrist (2009) and Costa and Rodrigues (2013) have recorded the intake solely of arthropods by P. cinerea. Conversely, Ribon (2002) says that the species eats mainly small seeds and fruits. Both studies contradict what we have found: prevalence of use of small invertebrates. Based on this prevalence, which is consistence across both areas, $P$. cinerea could be considered a specialist in eating small invertebrates (Fitzpatrick, 1980).

There is not much information on the diet of Poospiza species, other than their feeding guild. Other brazilian Poospiza species (P. cabanisi, P. melanoleuca, P. nigrorufa and $P$. torquata) are granivorous, omnivorous, granivourousfrugivorous or granivorous-insectivorous (Chatellenaz, 2004; Giraudo et al., 2006; Malizia et al., 2005; Scherer et al., 2005, 2007; Silva, 2006). Poospiza thoracica has a diet similar to that of $P$. cinerea, because it feeds mainly on arthropods $(64 \%, \mathrm{n}=170)$, but fruits $(23 \%, \mathrm{n}=170)$ and flowers $(13 \%, \mathrm{n}=170)$ represent a considerable amount of its diet (Parrini et al., 2009). However, it has been observed feeding on nectar, which did not occur with $P$. cinerea.
Registers from $P$. melanoleuca's diet, $P$. cinerea's sibling species, include Poaceae seeds and Cactaceae flowers (Di Giacomo, 2005); and also fruits, seeds and flowers (de la Peña and Pensiero, 2003).

According to Remsen and Robinson (1990), when classifying the adaptive syndromes of insectivorous birds, P. cinerea's syndrome would be near surface searching because it includes mostly near-pearch maneuvers, frequent hops and short-distance flights between areas. According to Eckhardt (1979), P. cinerea would belong to the guild gleaners, because it searches actively for prey difficult to spot and easy to capture.

Poospiza cinerea typically forages in intraspecific groups. In addition to that, we have observed in Area 2 that the species joins mixed bird flocks. Tubelis (2007) made a review of the Cerrado species that occur in mixed flocks, but $P$. cinerea, $S$. ruficapillus and $P$. guirahuro are not in his list. There are registers of $P$. melanoleuca and P. thoracica foraging in mixed bird flocks (Ridgely and Tudor, 1989; Di Giacomo, 2005).

In conclusion, Poospiza cinerea could only be considered a specialist in small invertebrates and near-perch maneuvers which are not really a niche constrain. We suggest that further studies investigate for a possible specialization within the category small invertebrates. The species has also proven to be quite plastic, being able to forage in exotic species whose characteristics do not match with the vegetation types of Cerrado. Therefore its rarity within the geographical range might be a consequence of other factors rather than foraging and diet specialization.

\section{Acknowledgements}

We would like to thank the anonymous reviewers and the editors for their suggestions that greatly improved the original manuscript. We thank Prof. G. W. Fernandes for allowing us to work in his property; ICMBio/CEMAVE for banding permits; the staff of Paredão da Serra do Curral Municipal Park and ICMBio Parna Serra do Cipó for permission to work in the areas. MR received fellowships from $\mathrm{CNPq}$ 
and FAPEMIG (PPM). FMS received an undergraduate scholarship from CNPq. MR thanks the 'Fundação Grupo Boticário de Proteção à Natureza' for supporting the 'Laboratório de Ornitologia' of 'Universidade Federal de Minas Gerais'.

\section{References}

BirdLife International, 2011. Species factsheet: Poospiza cinerea. Available from: http://www.birdlife.org. Access in: July 2012.

BROWN, JH., 1971. Mammals on mountaintops: nonequilibrium insular biogeography. American Naturalist, vol. 105, no. 945, p. 467-478. http://dx.doi.org/10.1086/282738.

CHATELLENAZ, ML., 2004. Avifauna del bosque de Quebracho colorado y Urunday del noroeste de Corrientes, Argentina. Facena, vol. 20 , no. 1, p. 3-12.

COSTA, LM. and RODRIGUES, M., 2012. Bird community structure and dynamics in the campos rupestres of southern Espinhaço Range, Brazil: diversity, phenology and conservation. Revista Brasileira de Ornitologia, vol. 20, no. 2, p. 132-147.

COSTA, LM. and RODRIGUES, M., 2013. Notes on residency, home range and natural history of the 'Vulnerable' Cinereous Warbling Finch Poospiza cinerea. The Wilson Journal of Ornithology, vol. 125 , no. 2, p. 433-438. http://dx.doi.org/10.1676/12-115.1.

DE LA PEÑA, MR. and PENSIERO, JF., 2003. Contribuición de la flora en los hábitos alimentarios de las aves en un bosque del centro de la provincia de Santa Fe, Argentina. Ornitologia Neotropical, vol. 14, p. 499-513.

DI GIACOMO, AG., 2005. Aves de la Reserva El Bagual. In DI GIACOMO, A. G. and KRAPOVICKAS, S. F. (Eds.). Historia natural y paisaje de la Reserva El Bagual, Provincia de Formosa, Argentina. Inventario de la fauna de vertebrados y de la flora vascular de un área protegida del Chaco Húmedo. Buenos Aires: Aves Argentinas/Asociación Ornitológica del Plata. p. 201-465. Temas de Naturaleza y conservación, vol. 4.

ECKHARDT, RC., 1979. The adaptive syndromes of two guilds of insectivorous birds in the Colorado Rocky Mountains. Ecological Monographs, vol. 49, no. 2, p. 129-149. http://dx.doi. org/10.2307/1942510.

ESPÍNDOLA, MB., BECHARA, FC., BAZZO, MS. and REIS, A., 2005. Recuperação ambiental e contaminação biológica: aspectos ecológicos e legais. Biotemas, vol. 18, no. 1, p. 27-38.

FITZPATRICK, JW., 1980. Foraging behavior of neotropical tyrant flycatchers. The Condor, vol. 82, no. 1, p. 43-57. http:// dx.doi.org/10.2307/1366784.

GIRAUDO, L., KUFNER, M., TORRES, R., TAMBURINI, D., BRIGUERA, V. and GAVIER, G., 2006. Avifauna del Bosque Chaqueño Oriental de la Provincia de Córdoba, Argentina. Ecología Aplicada, vol. 5, no. 2, p. 127-136.

GRUBB JUNIOR, TC., 1979. Factors controlling foraging strategies of insectivorous birds. In DICKSON, JG., CONNER, RN., FLEET, RR., JACKSON, JA. and KROLL, JC. The role of insectivorous birds in forest ecosystems. New York: Academic Press. p. 119-135.

LAIR, H., 1987. Estimating the Location of the Focal Center in Red Squirrel. Ecology, vol. 68, no. 4, p. 1092-1101. http://dx.doi. org/10.2307/1938381.

LOPES, LE., MALACCO, GB., ALTEFF, E., DE VASCONCELOS, MF., HOFFMANN, D. and SILVEIRA, LF., 2010. Range extensions and conservation of some threatened or little known Brazilian grassland birds. Bird Conservation International, vol. 20, no. 01, p. 84-94. http://dx.doi.org/10.1017/S0959270909990190.

MALIZIA, LR., BLENDINGER, PG., ALVAREZ, ME., RIVERA, LO., POLITI, N. and NICOLOSSI, G., 2005. Bird communities in Andean premontane forests of Northwestern Argentina. Ornitologia Neotropical, vol. 16, p. 231-251.

MEDINA, BMO. and FERNANDES, GW., 2007. The potential of natural regeneration of rocky outcrop vegetation on rupestrian field soils in "Serra do Cipó", Brazil. Revista Brasileira de Botânica, vol. 30, no. 4, p. 665-678. http://dx.doi.org/10.1590/ S0100-84042007000400011.

National Institute of Meteorology - INMET, 2011. Climatological graphics. Available from: http://www.inmet.gov.br. Access in: July 2013.

OLIVEIRA, PS. and MARQUIS, RJ., 2002. The cerrados of Brazil: ecology and natural history of a neotropical savanna. New York: Columbia University Press. 367 p.

PARRINI, R., PACHECO, JF. and MALLET-RODRIGUES, F., 2009. Comportamento de forrageamento de Poospiza thoracica (Passeriformes: Emberizidae) na Floresta Atlântica Alto-Montana do Parque Nacional da Serra dos Órgãos. Atualidades Ornitológicas, vol. 147 , no. 1 , p. $4-7$.

RABINOWITZ, D.,1981. Seven forms of rarity. In SYNGE, H. The biological aspects of rare plant conservation. Chichester: John Wiley \& Sons. p. 205-217.

RECHER, HF. and GEBSKI, V., 1990. Analysis of the foraging ecology of eucalypt forest birds: sequential versus single-point observations. Studies in Avian Biology, vol. 13, p. 174-180.

REMSEN, JV. and ROBINSON, SK., 1990. A classification scheme for foraging behavior of birds in terrestrial habitats. Studies in Avian Biology, vol. 13, p. 144-160.

RIBEIRO, J. and WALTER, B.,1998. Fitofisionomias do bioma Cerrado. In SANO, S.M. and ALMEIDA, SP. Cerrado: ambiente e flora. Planaltina: EMBRAPA-CPAC. p. 89-166.

RIBON, R., 2002. Colonization of eastern Brazil by the Cinereous Warbling-Finch, with some comments on its natural history. In Abstracts for the Third North American Ornithological Conference, 2002. New Orleans. New Orleans.

RIDGELY, RS. and TUDOR, G., 1989. Birds of South America: the oscine passerines. Austin: University of Texas Press. 516 p.

SANTANA, OA. and ENCINAS, JI., 2008. Levantamento das espécies exóticas arbóreas e seu impacto nas espécies nativas em áreas adjacentes a depósitos de resíduos domiciliares. Biotemas, vol. 21, no. 4, p. 29-38. http://dx.doi.org/10.5007/2175$7925.2008 \mathrm{v} 21 \mathrm{n} 4 \mathrm{p} 29$.

SAS Institute Inc, 2012. JMP, Version 10. Cary: SAS Institute Inc.

SCHERER, A., MARASCHIN-SILVA, F. and BAPTISTA, LRM., 2007. Padrões de interações mutualísticas entre espécies arbóreas e aves frugívoras em uma comunidade de restinga no Parque Estadual de Itapuã, RS, Brasil. Acta Botanica Brasilica, vol. 21, no. 1, p. 203-212. http://dx.doi.org/10.1590/S0102-33062007000100019.

SCHERER, A., SCHERER, SB., BUGONI, L., MOHR, LV., EFE, MA. and HARTZ, SM., 2005. Estrutura trófica da avifauna em oito parques da cidade de Porto Alegre, Rio Grande do Sul, Brasil. Ornithologia, vol. 1, no. 1, p. 25-32.

SICK, H., 1997. Ornitologia brasileira. Rio de Janeiro: Nova Fronteira. $912 \mathrm{p}$. 
SIGRIST,T., 2009. Guia de campo Avis Brasilis: avifauna brasileira: descrição das espécies. São Paulo: Avis Brasilis. 600 p.

SILVA, JMC., 1997. Endemic bird species and conservation in the Cerrado region, South America. Biodiversity and Conservation, vol. 6, no. 3, p. 435-450. http://dx.doi.org/10.1023/A:1018368809116.

SILVA, RRV., 2006. Estrutura de uma comunidade de aves em Caxias do Sul, Rio Grande do Sul, Brasil. Biociencias, vol. 14, no. 1, p. 27-36.

SODHI, NS., LIOW, LH. and BAZZAZ, FA., 2004. Avian extinctions from tropical and subtropical forests. Annual Review of Ecology Evolution and Systematics, vol. 35, no. 1, p. 323-345. http://dx.doi.org/10.1146/annurev.ecolsys.35.112202.130209.

SOUZA, VC. and LORENZI, H., 2008. Botânica sistemática: guia ilustrado para identificação das famílias de Fanerógamas nativas e exóticas no Brasil, baseado em APG II. 2nd ed. Nova Odessa: Instituto Plantarum. 704 p.

STOTZ, DF., FITZPATRICK, JW., PARKER iii, TA. and MOSKOVITS, DK., 1996. Neotropical birds: ecology and conservation. Chicago: University of Chicago Press. 478 p.
TUBELIS, DP., 2007. Mixed-species flocks of birds in the Cerrado, South America: a review. Ornitologia Neotropical, vol. 18 , p. $75-97$

VASCONCELOS, MF. and RODRIGUES, M., 2010. Patterns of geographic distribution and conservation of the open-habitat avifauna of southeastern Brazilian mountaintops (campos rupestres and campos de altitude). Papeís Avulsos de Zoologia, vol. 50, no. 1, p. 1-29. http://dx.doi.org/10.1590/S0031-10492010000100001

VASCONCELOS, MF., 2007. Aves observadas no Parque Paredão da Serra do Curral, Belo Horizonte, Minas Gerais, Brasil. Atualidades Ornitológicas, vol. 136, p. 6-11.

VICKERY, PD., TUBARO, PL., SILVA, JMC., PETERJOHN, BG., HERKERT, JR. and CAVALCANTI, RB., 1999. Conservation of grassland birds in the western hemisphere. Studies in Avian Biology, vol. 19, p. 2-26.

WISCHHOFF, U., MARQUES-SANTOS, F. and RODRIGUES, M., 2012. Nesting of the Cinereous Warbling Finch (Poospiza cinerea) in Southeastern Brazil. The Wilson Journal of Ornithology, vol. 124, no. 1, p. 166-169. http://dx.doi.org/10.1676/11-004.1. 